\title{
Kapitalizm Kadını Özgürleştirdi mi? Köleleştirdi mi? Soruları Bağlamında "Nefesim Kesilene Kadar" Filminin incelenmesi
}

BaşvuruTarihi: 16.11 .2020 Yayın Kabul Tarihi: $\quad 23.12 .2020$ Yayınlanma Tarihi: $\quad 30.12 .2020$

\author{
Ayşe Dudu Aydoğan ${ }^{1}$ \\ Aydın Adnan Menderes University \\ ayseaydogan.48@hotmail.com \\ (iD) ORCID: 0000-0002-1648-9002
}

\begin{abstract}
ÖZET
Kapitalizm ve ataerkillik arasındaki ilişki toplumsal cinsiyet bağlamında sinema üzerinden ele alındığında, yapılan çalışmalar önemli sonuçlar vermektedir. Endüstri Devrimi ile birlikte ortaya çıkan kapitalizm, kadının ve erkeğin emek piyasasındaki yerlerini etkilemekle kalmamış, ataerkil sistemin ideolojilerini de kullanarak üretim süreçlerine dâhil olma durumlarını değişime uğratmıştır. Kapitalizmin, mülkiyet kavramının değişmesiyle birlikte ekonomi ve aile kurumları üzerinde güçlü etkiler yaratmasıyla birlikte kadının toplumsal konumunda da değişiklikler meydan gelmiştir. Bu noktada çağdaş (modern) anlatı sineması kadının toplumsal değişim içerisindeki konumunu ele alış biçimi bakımından önemli bir gösterge alanı sunmaktadır. Emine Emel Balcı'nın ilk uzun filmi olan Nefesim Kesilene Kadar (2015) da kadının kapitalizm ve ataerkillik arasında nasıl sömürüye uğradığını gerçekçi bir şekilde anlatan önemli filmlerden birisi olmuştur. Kadının uğradığı sömürüyü kapitalizm ve ataerkillik kavramları ekseninde ele alan bu film, aynı zamanda bu ikili yapı ortaklığı ile kadın kimliğinin toplumsal varoluş içerisinde nasıl oluştuğunu ve geleneksel (klasik) anlatı yapısının hâkim olduğu filmlere göre kadın kimliğinin nasıl farklılaştığını görünür kılmıştır. Bu bağlamlar üzerinden ele alınan filmdeki kadın imgesi; kapitalizm, değişen mülkiyet ilişkileri sonucunda ataerkil ideolojinin güçlenmesi ve tüm bunlar sonucunda kadının özgürleşmekten çok "köleliğe" mahkûm edilip edilmediği sorusu etrafında değerlendirilmiştir. Bu değerlendirmeler yapılırken, çalışmanın kuramsal kısmı kültür, iletişim ve sosyoloji kuramları temelinde şekillendirilmiş; çalışmanın konusu ise yorumlayıcı sosyal bilimler yaklaşımı çerçevesinde ortaya konulmaya çalışılmıştır. Kadının kapitalizm ve ataerkillik arasında nasıl konumlandırıldığına dair yapılan emek sömürüsü tartışmasının, bu film ile birlikte ikili yapı arasında kadının çifte bir sömürüye uğrayarak özgürlükten çok sıkışmışlık durumunun daha da perçinlendiği sonucuna ulaşılmıştır.
\end{abstract}

Anahtar Kelimeler: Kapitalizm, Ataerkillik, Nefesim Kesilene Kadar, Emek Sömürüsü, Kadın Kimliği.

\footnotetext{
1 Yüksek Lisans Öğrencisi. Aydın Adnan Menderes Üniversitesi.
} 


\title{
Did Capitalizm Help Liberate Women? Did It Enslave Them? Review of the Movie "Nefesim Kesilene Kadar" in the Concept of These Questions
}

Application Date: 16.11.2020 Accepted Date: 23.12 .2020 Publishing Date: 30.12 .2020

\author{
Ayşe Dudu Aydoğan ${ }^{2}$ \\ Aydın Adnan Menderes University \\ ayseaydogan.48@hotmail.com \\ D ORCID: 0000-0002-1648-9002
}

\begin{abstract}
When the relationship between capitalism and patriarchy within the context of gender roles is dealt with cinema, the studies which are done give important results. Capitalism, which emerges with Industrial Revolution, does not only effect the places of woman and man in the labour market, both also causes a change in the situation of including them into production process by using patriarchal ideologies. Besides there has been some changes in the place of woman because of the fact that the notion of property has changed with capitalism and capitalism has produced a strong effect on economy and institution of family. Woman has been pushed into second place by losing her previous social station and exploited in the dual structure. At this point, contemporary narrative cinema plays a significant role in terms of handling the dual exploitation of the woman. Nefesim Kesilene Kadar (2015), which is the first full-length film of Emine Emel Balcl, is one of the most important films to tell realistically how a woman exploits between capitalism and patriarchy. The movie is, approaching with the exploitation of woman in the axis of the capitalism and patriarchy, also made objectify how woman's identity is formed in social existence and how woman's identities differ, compared to films that dominated by structure of traditional (classic) narrative. Therefore, the image of woman identity which is told in the film from this perspective has been evaluated among the effects of capitalism, getting strong patriarchal ideology because of the problems of the changing property relationship and the question of is the woman convicted to slavery rather than freedom. When these evaluations are being carried out, the method of the study has been gotten shape in the basis for the theories of culture, communication and sociology and the subject matter has been studied from the perspective of commentative social sciences approach. In this study, the fact that woman is expoited by both capitalism and patriarchy rather than freedom has been made up by discussing labour exploitation of how the woman is placed between capitalism and patriarchy.
\end{abstract}

Keywords: Capitalism, Patriarchy, Nefesim Kesilene Kadar, Labour Exploitation, Woman.

\footnotetext{
${ }^{2}$ Graduate Student. Aydın Adnan Menderes University.
} 


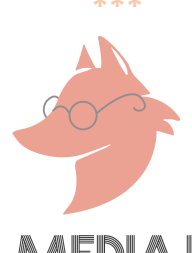

\section{GíRiş}

"Kadının sadece çalışıp gelir elde etmesi ile özgürlüğü elde etmenin aynı şey olmadığını belirten Beauvoir: üretim ilişkileri ile kadının çalışmasına rağmen bağımsızıı endişesini dile getirmektedir" (Yıldııı, 2019, s. 147). Bu endişe ise tam bir özgürlük mü sağlandı yoksa var olan durumu daha da kötü etkileyerek zorunlu bir köleliği mi doğurdu konusu ile tartışmalı bir hale dönüşmektedir. Bu bağlam içerisinde gücü elinde bulunduran ve sınıfı bir toplum yapısını oluşturan, aynı zamanda bu yapının sınırlarını belirleyen kapitalizmin, üretim sürecinde ataerkil yapı ile iş birliği içerisinde toplumsal cinsiyetin hatlarını çizen bir rolü olduğu da es geçilmemelidir. Kadın, bu ikili yapı içerisinde toplumsal cinsiyet katmanlarının içerisine girerken, sermayenin ve eril düşüncenin kendisine bakışı oldukça belirleyici bir unsurdur. Toplumların değişim ve dönüşüm sürecinde ekonomi önemli bir ölçüt olmuştur. Ekonominin ve üretim araçlarının mülkiyetinin değişmesi, toplumların değişime uğramasında ilk hareket noktasını oluşturmuştur. Bu değişimle birlikte sınıf mücadelelerinin ortaya çıkması toplumsal cinsiyet kalıplarının yanı sıra kadın ve erkeğin üretim sürecindeki konumlarını da etkilemiştir. Toplumsal cinsiyet kalıplarının oluşumunu etkileyen ilk dönüşüm ise avcı-toplayıcı toplumlardan tarım toplumuna doğru geçişle başlamıştır. Buradaki en önemli etken erkeğin üretim araçlarının mülkiyetini eline alması olmuştur. Bu bağlam içerisinde makalede öncelikle toplumların yaşadığı değişim süreçleri daha sonra ise bu süreçler içerisinde kadının toplumsal alanda ve özellikle üretim sahasındaki değişen konumu tartışılacaktır. Bu nedenle mülkiyet kavramı sonucunda ortaya çıkan emek sömürüsü ve ataerkil düzenin tüm bu süreçler içerisinde etkisi çalışmanın merkezini oluşturacak konulardandır. Mülkiyet kavramının nasıl bir dönüşüm geçirdiği ve sanayileşme ile birlikte ortaya çıkan kapitalizmin emek sömürüsünü nasıl ortaya çıkardığı değerlendirilecek ve sonrasında da ataerkil sistem ile birlikte cinsler arası ayrışmayı nasıl gerçekleştirdiği tartışılacaktır.

Tüm bu kavramsal çerçevenin yönlendirmesine bağıı kalınarak sinema, özelinde ise çağdaş anlatı sinemasında, Emine Emel Balcı'nın yönettiği önemli örneklerden birisini oluşturabilecek Nefesim Kesilene Kadar filmi incelemeye alınacaktır. Bu film hem kapitalizm hem de ataerkil sistem içerisinde kadının uğradığı sömürüyü tartışmaya açması bakımından önemli göstergeler sunmaktadır. Çağdaş anlatı yapısını kullanan bu film, gerçek kadın tiplemelerini ortaya koyması, ikili yapı arasında iş birliğini sorgulamaya açması bakımından özgürlük ve kölelik arasında kalan kadının nasıl temsil edildiğini gerçekçi bir çerçevede yansıtmaktadır.

\section{Kapitalizm Bağlamında Mülkiyet ve Emek Sömürüsü}

Endüstri Devrimi ile birlikte ortaya çıkan sanayileşme süreci birçok toplumsal değişimi ve dönüşümü de beraberinde getirmiştir. Kendinden önceki bütün toplum türlerini değiştirerek yeni bir toplum ve ekonomi anlayışı doğurmuştur. Giddens ise sanayileşmeyi tek bir soru üzerinden şu şekilde açıklar. "iki yüzyıl öncesine kadar tarihin bütününde egemen olan toplum türlerini ortadan kaldıracak ne olmuştur? Bu sorunun yanıtı, tek bir sözcükle sanayileşmedir" 


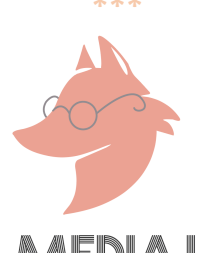

(Giddens, 2008, s. 73). Sanayileşme ile birlikte toplum yapısında, ekonomi anlayışında, aile kurumunda, üretim ve tüketim kültüründe değişiklikler meydana gelmiştir. Fakat sanayi öncesi toplumlara bakıldığında ise ilkel komünal toplumlarda sınıflı bir toplum yapısı varlığını göstermezken, ortak bir mülkiyet anlayışına sahip olan bu toplumlar avcı ve toplayıcılık yaparak yaşamlarını devam ettirmişlerdir. Gelişmiş bir iş bölümü anlayışları olmadığı için de herkes her işte görev alabilmiştir. "Ortak çalışma hem üretim araçlarının hem de ürünlerin ortak mülkiyetine yol açmıştı. O zamanlar ne sömürme vardı ne de sınıflar" (Stalin, 2009, s. 42). Insanlar vahşi hayvanları avlamak için birtakım aletler kullanırlar ancak onlar üzerinde de henüz bir hâkimiyet söz konusu değildir. Yine Kottak'ın (2008, s. 275) da ifade ettiği gibi "avcı ve toplayıcıların büyük çoğunluğu eşitlikçi toplumlardır". Eşitlikçi ve komünal sistemin egemen olduğu bu toplumlarda kadınlar ve erkekler arasındaki toplumsal cinsiyet tabakalaşmasına da rastlanmamıştır. Kadınlar toplayıcılıkla uğraşırken erkekler ise avcılıkla ve balıkçוlıkla uğraşmışlardır. Fakat "toplumsal cinsiyeti şekillendiren ve cinsler arası tabakalaşmayı arttıran en önemli etken ise üretim ritüelleri ile ilgili yaşanmış olan önemli değişimdir" (Aytekin, 2020, s.276).

Illkel komünal toplumdan tarım toplumuna geçiş sürecinde ise birtakım değişiklikler meydana gelmiştir. "Tarım toplumları, çiftçilik sistemlerinde bahçıvanlık ile hayvan yetiştiriciliğini birleştiren toplumlardır" (Marshall, 2014, s. 15). Bu toplumlarda artık hayvanlar evcilleştirilerek toprağın ekilip biçilmesinde kullanılmış ve besin üretim süreci hızlanmaya başlamıştır. Bunun sonucunda da yeni iş bölümleri ortaya çıkmıştır. Engels'in Ailenin, Özel Mülkiyetin ve Devletin Kökeni kitabında (1884/ 2003, s. 53) da ifade ettiği gibi "burada hayvanların evcilleştirilmesi ve sürüler yetiştirilmesi, o zamana kadar görülmemiş bir zenginlik kaynağını geliştirmiş ve yepyeni toplumsal ilişkiler yaratmıştır". Bu yeni toplumsal ilişkiler ise "köleci bir sistemin" doğmasına ve bunun sonucunda da sınıflı bir toplum yapısının ortaya çıkmasına neden olmuştur. Böylece bu köleci sistem ile birlikte ilkel komünal toplumlardaki kolektif mülkiyet anlayışı ortadan kalkmıştır ve birtakım eşitsizlikler meydana gelmiştir. Stalin'in de (2009, s. 43) ifadesiyle;

Artık burada, toplumun bütün üyelerinin üretim süreci içindeki ortak ve özgür çalışması görülmez; burada egemen olan şey, çalışmayan köle sahipleri tarafından sömürülen kölelerin zorla çalıştırılmasıdır. Onun için, artık burada üretim araçlarının ya da üretilen ürünlerin ortak mülkiyeti yoktur. Bunun yerini özel mülkiyet almıştır.

Ortaya çıkan bu özel mülkiyet anlayışının en önemli sonuçlarından birisi de kadının üretici konumunu kaybetmesi olmuştur. Bunun en önemli sebebi ise erkeğin sabanı elinde bulundurması ve kas gücü ile kullanmaya başlamasıdır. Engels'in $(2003$, s. 54) de bahsettiği gibi bu toplumlardaki iş bölümünde erkeğe bu aletleri kullanarak yiyeceği sağlama görevi düşer ve bunun sonucunda erkek bu aletlerin sahibi konumuna kolayca gelebilir. Dolayısıyla güç sahibi olan erkek özel mülkiyeti de tek bir elde toplayabilir. Bunun sonucunda Kottak'ın (2001, s. 453) 


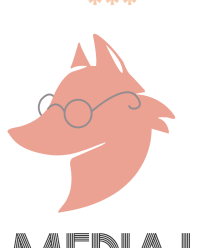

Cilt / Vol: $03-$ Sayı / No: $02 \quad$ | $\quad$ e-ISSN: 2757-6035

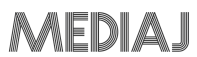

da söylediği gibi sabanın bir teknik olarak tarımsal üretimde kullanılması ve tarla tarımının yaygınlaşması ile birlikte kadın ilk kez insanlık tarihinde üretimden koparılır. Berktay (2016, s. 37) da kadının konumundaki bu düşüşü saban tarımının icadı ile birlikte güçlenen militarizmin, soy kavramının ortaya çıkarttığı akrabalık ve toplumsal cinsiyet ilişkilerinde önemli ölçüde değişime yol açtığını ve bu değişimler ile birlikte kabileler arasında kadınların değiş tokuş edilmesiyle kölelik sisteminin de ortaya çıkmasını kolaylaştırdığını açıklamıştır. Tam da bu noktada, daha sonra kadının tamamen denetim altına alınmasına neden olacak olan ataerkil sistemin temelleri atılmaya başlanmıştır. Ataerkil sistemde erkeğin özel mülkiyet kavramı ile birlikte değişen konumu, soyun devamını güvenceye alma meselesi ile tek eşliliğin ortaya çıkması, toplum içerisinde erkeğin konumunu daha güçlü hale getiren gelişmelerden biri olmuştur. Böylece, ataerkil sistem kendi içerisinde babalık hukukunu ortaya çıkarmış ve "analık hukukunun yıkılışı, kadın cinsinin büyük tarihsel yenilgisi olmuştur" (Engels, 2003, s. 56)

Sınıf ve cinsiyet tabakalaşmalarının gittikçe büyüdüğü, özel mülkiyet anlayışının kolektif mülkiyet anlayışını tamamen bitirdiği ve insanlar arasındaki sömürülerin artmaya başladığı feodal toplum modelinde ise köylünün toprağını elinde tutmaya başlayan feodal beyler veya toprak ağaları ortaya çıkmıştır. Stalin'in (2009, s. 44) de aktardığı gibi “burada özel mülkiyetin daha da gelişmiş olduğu görülmektedir. Sömürü, biraz hafifleşmiş olmakla birlikte, hemen hemen kölecilikte olduğu kadar zorludur. Sömürenlerle sömürülenler arasındaki sınıf savaşı, feodal sistemin ana çizgisini oluşturur". Bu toplumlarda, topraksız kalan köylü feodal beyler, toprak ağaları için çalışmaya başlamış ve ürettiklerine el konulmuştur. Tam da bu noktada insan emeğinin sömürülmeye başlandığı sınıfı bir toplum yapısı baş göstermiştir.

Georg Fülberth'in (2011, s. 90) Kapitalizmin Kısa Tarihi adlı kitabında da bahsettiği gibi, "feodalizmin toplumsal yapısı, toprak sahibi soylularla topraksız köylüler arasındaki ilişki tarafından belirleniyordu. Merkezi mülkiyet ilişkisi toprak mülkiyeti (toprak ağalığı) üzerine kurulmuştur". Dolayısıyla toplum ikiye bölünmüştür; toprağı elinde bulunduranlar ve onlar için çalışıp toprağı ekip biçerek yaşamını devam ettirmeye çalışanlar. Bu da ileride ortaya çıkacak olan kapitalist sınıfı toplum yapısının başlangıcı olmuştur. Köylüye işleyebileceği kadar toprak verilmiş ve üretim sonucunda ortaya çıkan artı-ürüne zorla el konulmuştur. Hilton (1984, s. 13) burada meseleyi "köylü aileye var olma-üretme için gereken mülkiyet verdikten sonra, artıürünün aktarılması zor kullanılarak gerçekleştirilir; çünkü ücretli-emekçinin tersine köylü, yaşamak için işgücünü yabancılaştırmak zorunda değildir" şeklinde açıklamıştır. Feodal toplumda ortaya çıkan önemli bir noktada kentlerin oluşmaya başlaması ve köyde toprağı işleyen köylünün karşında kentte çalışan ücretli emekçinin yer alması olmuştur. Marx ve Engels'in (1932/2003, s. 22) Alman Ideolojisi adlı kitaplarında da bahsettikleri gibi "toprak mülkiyetinin bu feodal yapısına, kentlerde lonca mülkiyeti, el zanaatlarının feodal örgütlenmesi tekabül ediyordu. Burada, mülkiyet esas olarak, her bireyin kendi emeğine bağıl bulunuyordu". Kentte zanaat anlayışının ortaya çıkmasıyla birlikte de atölye tarzı üretim sistemine geçilmeye başlanmış ve bu da usta- çırak ilişkisini doğurmuştur. Burada ortaya çıkan usta-çırak ilişkisi ise kırsaldaki 


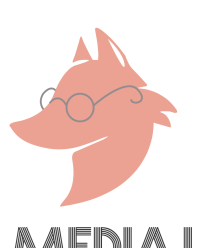

Cilt / Vol: $03-$ Sayı / No: $02 \quad$ | $\quad$ e-ISSN: 2757-6035

MEDIIAJ

toprak ağaları ile köylüler arasında görülen hiyerarşinin bir benzerini yansıtmıştır. Kısacası "sonradan modern fabrikalar için tipik olan iş bölümü buralarda yerleşik hale gelmeye başlamıştır" (Fülberth, 2011, s. 106). En sonunda ise bu atölyelerde kullanılan teknoloji daha sonra sanayi devrimi ile ortaya çıkacak olan kapitalist üretim sistemine de öncülük etmiştir ve sanayileşmeyi doğuran Endüstri Devrim'i ile birlikte de feodalizmin çöküşü gerçekleşmiştir. Marx'ın (2011, s.688) da söylediği gibi “kapitalist toplumun ekonomik yapısı, feodal toplumun ekonomik yapısından doğmuştur. Bu ikincisinin çözülmesiyle ilkinin unsurları serbest hale gelmiştir".

Endüstri devriminin oluşumunu tetikleyen iki önemli gelişme vardır; bunlardan ilki çıkrığın icat edilmesi, buharın ve suyun üretim sürecinde kullanılmaya başlaması olmuştur. İincisi ise bu ilk duruma bağıı olarak atölyelerin yerini büyük imalathanelere yani sanayilere bırakması olmuştur. Bu iki temel gelişme sonucunda da kapitalist bir sistem ortaya çıkmıştır. Kapitalist sistemin temel unsurları da "sermaye", "üretim araçlarının mülkiyeti" ve "emek" kavramlarıdır. Immanuel Walllerstein'in de ifade ettiği gibi, "kapitalizm her şeyden önce toplumsal bir sistemdir". Dolayısıyla kapitalizmi daha iyi anlayabilmek için kökenine ve işleyişine bakmak gereklidir. Kapitalizmin kilit öğesi olan sermaye de bu noktada önemli bir yere sahiptir. Sermaye, kapitalizm süreci içerisinde birikmiş zenginlikleri ifade etmek için kullanılmaktadır (2012, s.15). Bu yüzden de sermaye kapitalist sistemin güç kazanmasında önemli bir yere sahiptir. Çünkü "kapitalist sistem daha fazla sermayenin birikmesine, biriken bu sermayenin üretime dönüştüğü ve emek sermayesine dayanan bir sistemdir" (Çelik ve Dağ, 2017, s. 51) Bu noktada sermayeyi oluşturan ve bu birikmiş zenginliği elinde bulunduran sınıf da üretim araçlarına hâkim olan burjuva sınıfıdır. Dolayısıyla kapitalizmin önemli öğelerinden birisi olan mülkiyeti de bu hâkim sınıf oluşturmaktadır. Stalin'in (2009, s. 44) ifade ettiği gibi,

Kapitalist sistemde, üretim ilişkilerinin temeli, üretim araçları üzerindeki kapitalist mülkiyettir. Üreticiler üzerinde, yani ücretli iş̧̧iler üzerinde artık mülkiyet yoktur. Bu sistemde işçiler kişi olarak bağımlılıktan kurtuldukları için, kapitalist onları öl- düremez, satamaz; ama üretim araçlarından yoksun olduklarından, açlıktan ölmemek için işgücünü kapitaliste satmak ve sömürü boyunduruğuna katlanmak zorundadırlar.

Üretim araçlarının mülkiyetini elinde bulunduran bu burjuva sınıfının karşında ise üretim araçlarından kopartılan ve emeğini ücret karşılığında satmaya mahkûm bırakılan işçi sınıfı Marx'ın deyimiyle proletarya yer almaktadır. "Gelişmekte olan kapitalist sınıfın ilerlemesine aracılık eden bütün köklü dönüşümler, ama hepsinden önemlisi, büyük insan kitlelerinin geçim araçlarından birdenbire ve zorla koparılıp özgür ve korunmasız proleterler olarak emek piyasasına fırlatıldığı anlar, ilk birikim tarihinin çığır açıcılarıdır" (Marx, 2011, s.688). İnsanların üretim sürecinden yoksun bırakılması ise mülksüzleşmelerine yol açmıştır. Bu sonucunda ise işçi sınıfı emeğinin ücret karşılığı zengin sınıfa satmak durumunda kalmıştır. Dolayısıyla insanların emeği kapitalist üretim süreci içerisindeki iş piyasasında bir tüketim nesnesi gibi satılan ve elde 


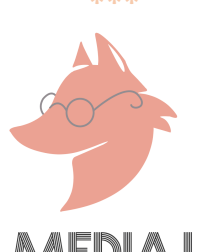

edilen bir metaya dönüşmüştür. "Bu demektir ki, sömürenlerle sömürülenler arasında çok zorlu bir sınıf savaşımı, kapitalist sistemin esas özelliğidir" (Stalin, 2009, s. 46).

Kapitalist toplumdaki cinsiyet tabakalaşmaları ise kendinden önceki toplum türlerine göre belirli noktalarda farklılıklar göstermiştir. Bu farklılıklardan en önemlisi de kadın, üretim süreci içerisinde büyük fabrikalarda yer almıştır. Engels'in (2003, s. 70) de söylediği gibi "büyük sanayi kadını evden kopararak emek pazarına ve fabrikaya gönderdiği ve onu çoğunlukla ailenin desteği durumuna getirdiğinden beri proleterin evinde erkek üstünlüğünün son kalıntısı da temelini" yitirmiş olur. Fakat buna rağmen kapitalist toplumda ataerkilliğin izleri görülmeye devam etmektedir. Bu yüzden de kapitalizm ve ataerkillik arasında çelişkili bir bağ vardır. Çünkü kadın iş hayatına katılmış olsa da ev yönetimi ve çocuk bakımı gibi ücretsiz ev işlerini de gerçekleştirmeye devam etmektedir. Tıpkı kapitalist sistemdeki burjuva ve proletarya arasındaki sömüren, sömürülen ilişkisi kapitalist toplumdaki ataerkil ailede de kendisini gösterir. Kısacası "aile içinde erkek burjuvazidir; kadın, proletarya rolünü oynar" (Engels, 2003, s. 71). Bu bağlam üzerinden ele alındığında kadın emek sömürüsüne uğrayan, erkek ise ataerkil sistemin devam ettiricisi konumuna gelir.

\section{Ataerkil Sistem ve Kapitalizm Arasında Tutsak Edilen Kadın}

Friedrich Engels (2003, s. 72) "aile içinde erkek burjuvazidir; kadın, proletarya rolünü oynar" derken kapitalizm ve ataerkillik arasındaki hem çelişkili hem de bütünleşik bir yapı içerisinde kadının emek sömürüsüne uğradığını açık bir biçimde ortaya koyar. Bu bağlamda şu söylenebilir, kapitalist bir sistem içerisinde maddi üretim araçlarını elinde bulunduran sınıf aynı zamanda toplum içerisinde egemen olan ideolojiyi de belirlemekte ve kendi ekonomik çıkarları doğrultusunda yönetmektedir. Dolayısıyla üretim araçlarına sahip olmayan ve emeğini satmak zorunda olan sınıf ise egemen sınıfın ideolojilerine tabi olmak zorunda kalır. Bu da demek oluyor ki, kapitalist ataerkil sistem içerisinde kadın hem ailede yani ev içinde hem de kamusal alana dâhil olarak üretim süreci içerisinde sömürüye uğrar. Maria Mies (2011, s. 92-93) Ataerki ve Birikim kitabında kadınların uğradığı bu sömürünün bir önceki bölümde de bahsedildiği üzere tarihsel bir süreci içerdiğini söyler. Toplumların uğradığı değişimler sonucunda ortaya çıkan ataerkil sistem tarafından yaratıldığını, sadece psikolojik ve biyolojik bir yönünün olmadığını bunun yanı sıra toplumsal bir süreç olduğunu da açıkça ifade etmektedir. Bu bağlam içerisinde de Maria-Rosa Dalla Costa ile birlikte kadınların uğradığı bu sömürüyü üçlü bir anlam içinde okumak gerektiğini söylemektedir: "Kadınlar erkekler tarafından (yalnızca ekonomik olarak değil, aynı zamanda insan olarak da) sömürülürler ve ev kadını olarak sermaye tarafından sömürülürler. Ücretli işçi olmaları durumunda, ayrıca ücretli- iş̧̧i olarak da sömürülürler". Bu demek oluyor ki kadının bu süreç içerisinde emek sömürüsüne uğramasının temel iki boyutu vardır. Illki tarihsel ve ekonomik bir süreç içerinde özel mülkiyet kavramının ortaya çıkmasıyla kadının ev içine çekilmesi bunun sonucunda da kadının ataerkil yapıya hizmet etmek zorunda bırakılmasıdır. İkincisi ise hızla gelişmeye devam eden endüstrileşme sürecinde, iş gücüne 


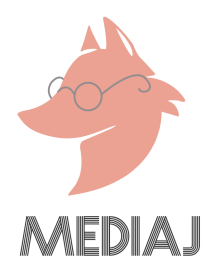

ihtiyacın duyulması ve kadınların endüstriyel üretim alanına dâhil edilerek ucuz iş gücü bağlamında emeğinin sömürülmesidir. Daha özet bir ifadeyle "aileye ait özel alanda ya da 'yeniden üretimde' kadınların ezilmesi 'ataerkinin' işidir ve ataerki üst yapının parçası olarak görülür, işyerinde ve fabrikada çalışan işçiler olarak sömürülmesi ise kapitalizmin işidir" (Mies, 2011, s. 95). Bu bağlamda ele alındığında, kadın hem ev içinde ücretlendirilememiş emek olarak yeniden üretim sürecine katılmakta hem de ücretli işçi olarak ekonomik anlamda iş sahasına dâhil olmaktadır. Connell'ın (2017, s. 90) da söylediği gibi “ideolojik açıdan hala güçlü olan, 'eve ekmek getiren koca' ve 'yuvayı yapan kadın' şeklindeki normatif örüntü, aslında ekonomi tarafından yıpratılmaktadır”. Ancak toplumun en küçük birimini oluşturan aile, ataerkil sistem ile birlikte kadını her durumda çevrelemeye devam etmektedir. Aksu Bora $(2018$, s. 40) da ikinci dalga feminist çalışmalarda, kadının ikincilleştirilmesinin ana nedeninin aile olarak görüldüğünü söylerken kadının toplumsal ve ekonomik yer alış biçimine dair eşitlik taleplerinin bu özel alan olan aileye dair ayrımcılığın ortadan kalkmadığı sürece gerçekleşmeyeceğini ifade eder. Bu perspektiften bakıldığında ataerkil düzen içerisinde kadının ev içi ücretsiz emeği ve kapitalist düzen içesinde ucuz iş gücü olarak çalıştırılması kadının toplumsal düzlemdeki konumunu tartışmalı hale getirir.

Kapitalizm süreci ile birlikte artan işgücü ihtiyacı ve buna bağlı olarak ortaya çıkan işgücü piyasası, cinsiyet gözetmeksizin hem erkeğe hem de kadına eşit olmayan koşullar sağlayan bir yapıya sahiptir. Fakat burada dikkat edilmesi gereken ve önemli bir sorun oluşturan nokta ise kadınların erkeklere göre daha dezavantajlı konumda olmalarıdır. "Günümüz kapitalist toplumunda kadınların emek piyasalarındaki konumu ve istihdam alanları daha çok esnek ve güvencesiz çalışma ile özetlenmektedir. Kadınlar genellikle iş güvencesinin olmadığı, sosyal güvenliğin bulunmadığı olumsuz çalışma koşulları altında, ucuza istihdam ediliyorlar" (Öztürk ve Dedeoğlu, 2010, s. 11). Çünkü kadınlar iş gücü piyasasına dâhil olurken burada yaptıkları işleri ikincil işler olarak görmektedirler. Kadınların birincil işler olarak gördükleri ise onların ev içi organizasyon sürecinde gerçekleştirdikleri, bir ücret talep etmeden karşılıksız yapmış oldukları işlerdir. Bu birincil işleri "ücretsiz aile iş̧̧iliği" olarak değerlendirmek de yerinde bir tespit olacaktır. Ecevit (1995, s. 119) kadınların bu işleri neden ikincil olarak tercih ettiklerini şu şekilde açıklar;

Kadınlar için ev dışında ücret karşılığı çalışmak birincil amaç değildir; kadınlar eğer çalışıyorlarsa, buna geçici ve zorunlu bir uğraş gözü ile bakarlar; esas bulunmak istedikleri alan ev, yağmak istedikleri faaliyetler de ev kadınlığı ve anneliktir. Kadınların kentsel ekonomik faaliyetlere niçin az katıldıkları, genellikle, onların ile içindeki rol ve bu role bağlı tercihleri ile ve aile içindeki ataerkil ilişkilerle açıklandı...

Mies (2011, s. 117) de bu konuya "kapitalizm koşullarında, bütün kadınlar toplumsal açıdan ev kadını olarak (bütün erkekler de eve ekmek getiren kişi olarak) tanımlanır ve annelik ise bu ev kadını sendromunun bir parçası ve bölümüdür" şeklinde bir tanımlama getirir. 


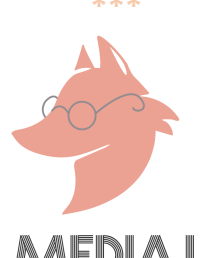

Bu bağlamda ele alındığında, güçlü ataerkil sistemin bir getirisi olarak kadınların ev işi ve bakım işi gibi işlerden sorumlu tutulmaları dolayısıyla bu işleri birincil işler konumuna yerleştirmeleri kapitalizminde çıkarına bir durum olmuştur. Erkekler fabrika iş̧̧isi olarak ücretli iş alanlarına dâhil olurken, "kadınlar ise ya üretim sürecinden dışlanmış ya da evlerde çalışmayı sürdürmüştür" (Toksöz, 2012, s. 51). Bu yüzden kadınlar genellikle aile gelirine destek olmak veya erkeğin işsiz kaldığı durumlarda ailenin geçimini üstlenmek üzere emek piyasasına dâhil olmak zorunda kalmışlardır. Dolayısıyla kadınlar ev dışında ücretli olarak yaptıkları bu işleri ikinci mesaileri olarak görmüşlerdir. Tam da bu noktada kadının emeği, erkek emeğinden ucuz bir konumda görülmüş ve bu durum kapitalist üretim süreci içerisinde sermaye için bir fırsat niteliği oluşturmuştur. Toksöz'ün (2012, s. 94-95) de söylediği gibi "aslında kadınlar evde erkekler için değil sermaye için emek harcalar. Çünkü kadının sunduğu hizmetlerin piyasadan temini durumunda işverenlerin ödemesi gereken ücretin çok daha yüksek olması gerekecektir. Kadının evdeki karşılıksız çalışması kapitalistlerin ücretleri düşük tutmasını ve işçileri daha çok sömürmesine imkân tanır". Böylece kapitalizm hem bu durumdan fayda sağlamış hem de kadının emeğinin sömürülmesine neden olmuştur.

Ataerkil ideolojinin ve kapitalizmin getirdiği cinsiyetçi iş bölümünden kaynaklı ortaya iki sonuç çıkmışır; birincisi kadınlar toplumsal üretimden uzak kalmışlardır. İkincisi ise kadınlar emek piyasası içerisinde erkeklere oranla daha fazla emek sömürüsüne uğramışlardır. Necla Arat'ın (1996, s. 45-46) da bahsettiği gibi "kadınlar bu yüzden daha çok hizmet sektöründe, sağlık, eğitim, tekstil, gıda vb. alanlarda kitlesel bir biçimde çalışırlar. Eşit işe eşit ücret yasalarına rağmen ücretleri erkeklerinkinden daha düşüktür. Ekonomik bunalım dönemlerinde ya öncelikle işten çıkarıırlar ya da part-time olarak çalışmaya yönlendirilirler". Bu yüzden de kadınlar enformel ve yarı zamanlı işlerde çalışmak zorunda kaldılar. Görüldüğü üzere kapitalizm hem ataerkil sistemin ideolojilerinden faydalanmış hem de bu sistemin aile modelini bozmayacak ve kadının ev içinde çalışmasını engellemeyecek şekilde emek piyasasına ucuz iş gücü olarak entegre etmiştir. Dolayısıyla kadınlar emek piyasasında ucuz iş gücü olarak hem tercih edilen hem de kolayca işten çıkarılabilen bir konumda yer almışlardır.

Sonuç olarak kadınlar özel mülkiyetin ortaya çıkmasıyla emek sürecinden bir kopuş yaşadı fakat kapitalizm ile birlikte hızla gelişen endüstrileşme sonucu tekrar emek sürecine dâhil edilir. Tam da bu noktadan hareket edildiğinde ise kadının özgürleşmesi beklenirken ikili bir kıskaç altına alındığı açıkça görülmektedir. Bu durumda Zetkin'in $(1996$, s. 15) de ifade ettiği şekliyle, kadının faaliyet alanı ev içinden toplum içine doğru kaydırılır. Kapitalist sistemin gücüyle birlikte sanayinin göbeğine fırlatılan kadın, daha önceleri kolay iş umudu için gittiği fabrikada artık tutsak haline gelir. Bu bağlamda ele alındığında kadının ataerkil yapı ile kapitalizmin sömürüye dayanan yapısı içerisinde, düşük ücret alarak kötü çalışma koşullarında yaşamını devam ettirmesinin onu özgürleştirmediğini tam aksine daha da köleleştirdiğini söylemek mümkündür. Bu yaklaşıma bağlı kalınarak, konuyu temsil niteliğinde ise Nefesim Kesilene Kadar filmi üzerine bir okuma çalışması yapılacaktır. 


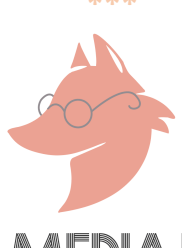

\section{Nefesim Kesilene Kadar: Özgürlük mü? Kölelik mi?}

Kadın emeğini ele alırken hem ataerkillik hem de kapitalizm açısından ele almak önemli bir yere sahiptir. Çünkü her ikisi de kadını çevreleyen yapılardır ve kadınların çifte sömürüye uğramasına yol açmaktadırlar. Bu ikili yapı birbirinden beslenerek ortak mekanizmalar aracılığıyla kadının sadece sömürüye uğramasına değil bunun yeniden üretim aracılığıyla tekrar edilmesine neden olmaktadır. Connell $(2017$, s. 78 ) daha tanımlayıcı bir çerçeve içerisinde, aile, cinsiyet ve toplumsal cinsiyet gibi ilişkilerin yeniden üretim alanı olduğunu ve bu bağlamda da ataerkillik ve kapitalizm arasında sıkı bir bağ oluşturarak kadını çevreleyen ilişkiler ağında önemli bir yere sahip olduğunu açık bir şekilde ifade eder. Kadın bu ilişkiler ağı içerisinde hem aileye hem de üretim sürecine tabi kılınır. Connell’ın (2017, s. 78) da ifadesiyle, "yeniden üretim" kapitalizmin üretim alanlarının dışında kalan boşlukları doldurmak üzere kadının çocuk doğurması ve üretim sürecinde işçi olarak çalışan erkeğe hizmet etmesi olarak değerlendirilebilir. Kısacası bu yeniden üretim sistemleri kadının çalışması ve kapitalist düzen içerisinde özgürleşmesini engelleyici unsurlar bütününü oluşturmaktadır.

Sinema da bu ikili yapı arasındaki ilişkiden beslenmekte ve yeniden üretim kodlarına ilişkin ipuçlarını bulmada önemli bir uygulama alanı sunmaktadır. Smelik 'in $(2008$, s. 1) söylediği gibi "sinema, kadınlar ve dişillik ile erkekler ve erillik, kısacası cinsel farklılıklar üzerine mitlerin üretildiği, yeniden üretildiği ve bunların temsil edildiği kültürel bir pratiktir”. Jill Nelmes'ın da Sinemada Cinsiyet ve Cinselliğin Sunumu adlı makalesinde altını çizdiği şekliyle sinema feminizmin ilk dönemlerinden itibaren kadın ve erkek imgelerine dair bir mücadele alanı oluşturmuştur. "Film, erkeklerin egemenliğindeki medyanın sunduğu tek tipleştirilmiş kadın imgelerine karşı koyacak ve kadınların genellikle bağımlı roller üstlendikleri erkek egemen toplumdaki ikincil konumlarının farkına varmalarını sağlayacak ideolojik bir aygıt olarak kullanılabilirdi”3. Dolaysıyla sinema, kadının erkek karşısındaki eşitsiz konumunu anlamamız açısından birçok açıklama getirir.

Nilgün Abisel Türk Sineması Üzerine Yazılar kitabında filmlerin toplumsal yapıya ait kültürü ve değer yargılarını yansıtması bakımından içinde yaşadığımız gündelik dünyaya ilişkin bilgiler sunduğunu ifade etmektedir. Bu nedenle Abisel'e göre, bu filmler "kadınların Türkiye'deki toplumsal konumunun anlaşılması açısından çok elverişli bir inceleme malzemesi sunmaktadır" (2005, s. 295). Dolayısıyla kadınların, filmlerdeki konumlarını sinemada genel kabul gören ve iki farklı düzlemde ilerleyen anlatı yapısı üzerinden ele alabiliriz. Bunlardan ilki, sinemada ataerkil yapının ideolojilerini kadın karakterler üzerinde güçlü bir şekilde kuran "klasik (geleneksel) anlatı" sinemasıdır. Klasik anlatının kullanıldığı filmlerde kadına biçilen iki rol vardır; ataerkil yapının belirlediği ve toplumsal cinsiyet rollerine uygun hareket edenler ve bunun dışına çıkanlar. Rolüne uygun davranan "iyi kadın" olarak nitelendirilirken bunun dışına çıkanlar ise

3 Jill Nelmes, Sinema Cinsiyetin ve Cinselliğin Sunumu, https://kaosgl.org/haber/sinemada-cinsiyet-ve-cinselliginsunumu. 


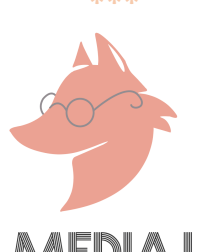

"kötü kadın" olarak nitelendirilmişlerdir ve stereotipleşmiş olan bu kadın kimliklerinin dışına neredeyse hiç çıkılmamıştır. Klasik anlatının hâkim olduğu filmler uzun anlatım tarzını sahip öyküler içerir ve karakterler üzerinden seyirciye mesaj vermeyi hedefler. Dolayısıyla Büker'in (1989, s. 97) de söylediği gibi "geleneksel anlatı filmlerinin başkalarına uzun uzun anlatabileceğimiz öyküleri vardır. Öyküdeki olaylar neden-sonuç ilişkileri ile birbirine bağlanır".

Klasik anlatı yapısını içeren filmler kadın kimliklerini oluşturmada ise "eril bakışı" kullanmıştır. Mulvey'in (2019, s. 209) erkek egemen bakış açısını vurguladığı "Görsel Haz ve Anlatı Sineması" adlı makalesinde de bahsettiği gibi "erkek film fantezisini denetler ve aynı zamanda daha öte bir anlamda iktidarın temsilcisi olarak ortaya çıkar". Böylece bu filmlerde ortaya çıkan kadın imgesi, eril dil bağlamında yaratılmaktadır ve ataerkil ideolojiye hizmet edecek şekilde denetlenmektedir. Türkiye'de 2000 'lere gelindiğinde ise yaşanan hızlı endüstrileşme süreci sonucunda ortaya çıkan gelir eşitsizlikleri, gelişen teknoloji sonucunda insanların fabrikalarda ve atölyelerde iş̧̧i olarak çalışmaya başlamaları, tüm bunlara bağlı olarak gerçekleşen göçler ile birlikte kentin değişen yapısı da Türk sinemasındaki filmlerin konularında ve anlatı yapısında değişime neden olmuştur. 2000'li yıllarda ortaya çıkan yeni kuşak yönetmenlerde farklı sinematik dil yapısını ve anlatım tekniklerini kullanarak feminist film pratiği açısından katkı sağlayan filmlerle kadınların görünürlüğünü daha fazla arttırmışlardır. Buna bağlı olarak, filmlerdeki kadın imgeleri de değişime uğramıştır. Giovanni Scognamillo'nun (2014, s.451-52) Türk Sinema Tarihi adlı kitabında altını çizdiği şekliyle 2000'li yılların Türk sineması, toplumsal ve siyasal gündemi ile farklı bir alan sunmaktadır. Büyük kentler, ekonomik krizler ve bireylerin marjinalleşmesi gibi konular ile birlikte gündemi takip etmiş ve toplumsal sorunlar üzerine eğilmeye çalışılmıştır. Bu açıdan Scognamillo'ya göre bu dönem Türk sineması "yeni kuşak sineması" olma yolunda ilerlemektedir. Artık klasik anlatının hâkim olduğu filmlerin karşısında, toplumsal konulara ve bireylerin sorunlarına daha çok odaklanan çağdaş (modern) anlatı yapısının kullanıldığı filmler yer almaktadır. Suner $(2006$, s. 37) de bu filmlerin daha önce yapılmış hiçbir filme benzemediğini, işlediği konu, üslup, kurgu bakımından da farklılık gösterdiğini ve $2000^{\prime} l i$ yıllarda bu filmlerin daha da su yüzüne çıkmasıyla yeni bir dönemin habercisi olduğunu ifade eder.

Klasik anlatı sinemasının aksine çağdaş anlatı sineması toplumsal cinsiyet kalıplarını da yıkan bir söyleme sahiptir. Bu anlatı yapısının kullanıldığı filmlerde ise kadın ve erkek kimliklerine dair stereotipleşmiş imgeler yer almaz. Çağdaş anlatı sinemasında, karakterler ve filmin ortaya koyduğu sorun tartışmaya açıktır. Claire Johnston (akt. Smelik, 2008, s. 4) ise klasik sinemada kadın üzerine yaptığı okumasında kadının erkek ideolojiye hizmet edecek şekilde konumlandırıldığından ve kadının erkek karşında "erkek olmayan" olarak tanımlanması sonucu kadınlık hallerinin yok sayıldığından bahseder. Dolaysıyla bu filmlerde kadınlar gerçekten uzak fakat gerçekmiş gibi seyirciye sunulmaktadır. Daha özet bir ifadeyle klasik anlatı sinemasında erkekler genellikle özne konumunda etkin bir şekilde yer alırken, kadınlar ise nesne durumunda ve edilgen bir konumdadır. (Hayward, 2000, s. 256). Ancak çağdaş sinemada yer alan kadın 


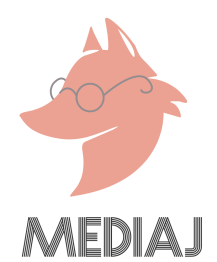

imgesi süreç içerisinde belirgin farklılıklar yaşamıştır. Öztürk' ün (2000, s.75) de söylediği gibi “bu filmlerde kadına bakış daha özneldir; kadınlar fethedilmeyi bekleyen nesneler olmaktan çok, yaşama mücadelesi içinde yer alan bireyler olarak konumlanırlar". Böylece kadınlar filmlerde nesne değil özne olarak yer alırlar ve kamusal alana dâhil olarak film içerisinde daha gerçekçi mekânlarda ön plana çıkarlar. Bu bağlamda ele alacağımız film ise çağdaş anlatı sineması kanadında yer alan ve belgesel sinema kökeninden gelen Emine Emel Balcı'nın hem yazıp hem yönetmenliğini yapmış olduğu "Nefesim Kesilene Kadar" filmidir.

Film, tek amacı babası ile bir hayat kurmak isteyen fakat bu süreç içerisinde ablası ve eniştesi ile birlikte yaşamak zorunda bırakılan güçlü bir kadın olan Serap'ın mücadelesini anlatmaktadır. Film boyunca karşılaştığı durumlara bağlı olarak iyilik ve kötülük arasında bocalayan bir kadının hikâyesini izleriz. Ancak filmin arka planında, bir amaca ulaşabilmek için çalışmak zorunda olan Serap'ın "işçi bir kadın" olarak yaşadığı zorlukları görürüz. Film bu bağlamda ataerkil yapı ve kapitalizm arasında konumlandırılmış kadın imgesini gerçekçi bir şekilde ortaya koymaktadır. Filmin ilk açılış sahnesinde kameranın Serap'ı arkadan takip ettiğini görürüz. Balcı, bu noktada klasik anlatı sinemasından farklı bir kamera açısı kullanmış ve Serap'ı doğal yaşamı içerisinde incelemeye koyulmuştur. Burada dikkat çeken bir diğer konu ise çağdaş anlatı sinemasında kullanılan kamera ve görüntünün klasik anlatı sinemasına göre farklılıklar göstermesidir. Klasik anlatı sinemasında görüntüler ve kamera hareketli bir şekilde ilerlerken, çağdaş anlatı sinemasında kamera izlediği karakteri arkasından takip edercesine çok yakın bir plandan çekmektedir. Serap, babasını aramak için erkeklerin çoğunlukta bulunduğu bir alana dâhil olur ve gece olana kadar babasını aramaya devam eder. Burada dikkat çeken nokta ise Serap'ın erkeklere ait olduğu düşünülen kamusal alana korkusuzca dâhil olmasıdır. Dolayısıyla kadın imgesinin artık değişmekte olduğunu, gerçekmiş gibi gösterilen kadınlardan gerçek kadın imgelerine doğru bir geçişin olduğunu açıkça görebiliriz. Bir diğer taraftan ise Serap'ın babasını ararken aynı zamanda iş yerinden bir arkadaşı ile telefon görüşmesine şahit oluruz. Serap hem ailesinde en değer verdiği kişi olan babası için endişelenmekte hem de işini kaybetme korkusu yaşamaktadır.

Serap'ın babasının yanından ayrılıp, ablası ve eniştesi ile birlikte yaşadığı eve girmeden önce kazandığı parayı ayakkabısının içine saklaması ve bu parayı eniştesine vermediği için sorguya çekildiği sahnede ise ataerkil sistemin aracısı olan erkek tarafından kadının sömürüye uğradığı açık bir şekilde ifade edilmektedir. Bir önceki bölümde de bahsedildiği gibi "eve ekmek getiren koca" bu sistem içerisinde "aile reisi" konumunu da elde etmektedir. Filmde Serap'ın eniştesi de aile reisi konumunda yer alır ve evin diğer üyeleri olan kadınlar üzerinde tahakküm kurmaya çalışır. Serpil Sancar'ın erkeklik üzerine kaleme aldığı Erkeklik: Imkânsız Iktidar kitabında da altını çizdiği şekliyle "alt sınıf mensubu erkeklerin yani 'ailenin reisleri ve piyasanın işçilerinin' aile içinde tahakkümcü, dışarıda maço erkekler oldukları genel kabul gören bir saptamadır" (2013, s. 99). Filmde Serap ve ablası eniştesi tarafından eril bir tahakküme kurban edilirken, erkek ise hükmeden konumunda yer almakta hatta şiddet uygulayarak bunu kendisine hak görmektedir. Dolayısıyla Bourdieu'nün (2018, s. 67) da ifade ettiği gibi toplumsallaşma 


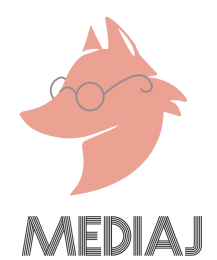

süreci içerisinde yok sayma ve aşağı görme ile birlikte zorla boyun eğdirilen kadınlar, teslim olma ve sessizliğe mahkûm bırakılırken erkekler ise bu durumun tam karşında hükmeden olarak yer alırlar. Diğer bir taraftan Virginia Woolf (2018, s. 40-41) ise bu durumu yüzyıllar boyunca kadınların, erkekleri olduğundan büyük gösteren ve onları olumlayan bir ayna görevi gördükleri şeklinde açıklar. Çünkü erkeklerin gerçekleştirdiği bütün şiddet ve kahramanlık eylemlerine ayna gereklidir bu görevde ataerkil sistemin aracılığı ile kadına yüklenmektedir.

Filmde dikkat çeken bir diğer karakter ise Serap’ın ablasıdır. Evin karanlık ve sessiz yapısı içerisinde abla mutsuz bir evliliğe ve kısıtlanmış bir hayata sahiptir. Abla sessiz bir şekilde erkeğin söylediklerini yerine getirmekte ve ataerkil sistem karşısında dilsizleşmektedir. Connell (2017, s. 268) bu şekilde kadınların erkeklere tabi kılındığını ve bu tabi kılınma karşısında kadınların bir boyun eğiş tavrı sergileyerek erkeklerin çıkarlarına hizmet etmeye başladığını söylemektedir. Bu kadınlık biçimini de "ön plana çıkarılmış kadınlık" olarak adlandırmaktadır. Kocanın, ablaya "otur sen yemeğini ye" söylemi ve aynı sahne içerisinde para bulabilmek için Serap’ın çantasını kocası istediği için sorgulamaksızın araması da kadının ataerkil karşındaki pasif konumunu perçinlemektedir. "Ataerkil kültürde kadın, hâlâ anlam yapıcı değil anlam taşıyıcısı konumuna bağımlı olan sessiz imgesi üzerine erkeğin, dilsel komuta aracılığıyla zorla yüklediği fantezi ve takıntılarını sonuna kadar yaşayabileceği bir düzenle kuşatılmış olarak erkek öteki için bir gösteren yerine geçer" (Mulvey, 2019, s.202). Bu nedenle filmde, Serap'ın eniştesi etken konumda yer alırken ablası ise kocasının söylediklerini yerine getirerek edilgen bir konuma yerleşmektedir.

Sabahın erken saatlerinde Serap aynı mahalleden iş arkadaşı Dilber ile birlikte kadınların işe gitmek için toplandıkları yere doğru yürürler. Bu sahnede dikkat edilmesi gereken iki önemli nokta vardır. Bunlardan ilki servise yetişmek için aceleyle yürüdükleri sahnedir ve Dilber'in işten para aldıklarını ama bir şeye yaramadığını dolayısıyla da işe hiç gitmek istemediğinden bahsetmesidir. İkinci önemli nokta ise kadınların kapalı kasa bir araç içerisinde, kötü koşullarda iş yerine götürülmesidir. Kapitalizm kadınları iş hayatına dahil eder fakat kadınlar hem ikincil iş kolu olarak görülen enformel işlerde yer alırlar hem de kötü ve elverişsiz koşullar içerisinde çalışmaya zorlanırlar. Şenses (2001, s.177) de kadınların işgücü piyasasına katılmalarına rağmen birtakım ayrımcılıklara maruz kaldıklarını, işgücüne katıldıktan sonra ise enformel sektörde ağılıklı olmak üzere genelde düşük kaliteli işlerde çalıştırıldıklarını ve çoğu zaman erkeklerle aynı işleri yapmalarına rağmen daha düşük ücret aldıklarını ifade eder. Serap'ın yarım gün işe gelmediği için ustabaşı tarafından parasının eksik verilmesi parasını tam bir şekilde alabilmesi içinde mesaiye kalmak zorunda olması, kapitalist sistem içerisinde yer alan iş̧̧ilerin çalışma saatlerini tamamlamadıkları durumda aldıkları ücretten mahrum bırakılabileceğinin ve ücretini tam alabilmesi için daha fazla çalışması gerektiğinin bir göstergesidir. Ataerkil yapı ile arasındaki bağı anlatan bir diğer sahne Serap'ın eve gittiğinde odasının dağınık olması ve eniştesinin eşyalarının arasında para aramasıdır. 


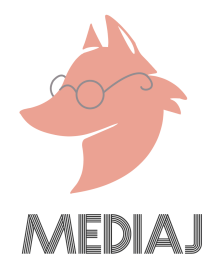

Serap eniştesine parası olmadığını söyler fakat eniştesinin yaşadıkları evin onun olmadığını ve para getirmesi gerektiğini söylemesi ile bu ikili yapı arasında ki ilişkiyi anlatan söylemler iyice belirginleşir. Tam da bu noktadan hareketle Mies'in (2011, s. 95) de söylediği gibi "ataerki kavramı, kadınların sömürülmesi ve ezilmesinin tarihsel derinliğini gösterirken, kapitalizm kavramı, bu sistemin çağdaş tezahürünü ya da en son gelişmiş halini anlatır". Kapitalizm ve ataerkillik arasında ki ilişki de çağdaş anlatı sineması tarafından gerçekçi bir şekilde ortaya konmuş olur. Filmde Serap'ın eniştesi ataerkil sistemin devam ettirici niteliğinde bir erkek tiplemesi oluşturmaktadır. Serap'ın parasını elinden alması ve ablasına da ev içindeki işleri yaptırması bu durumun en önemli göstergesidir. Kadının kamusal alan olan iş yerlerinde zor şartlarda çalışması sömürünün gelişmişliğini gösterirken, özel alan olan evlerde enişte, abi ve baba gibi erkek üyeler tarafından kazançlarına el konulması sömürünün tarihsel derinliğine işaret etmektedir.

Serap'ın tek isteği ablası ve eniştesi ile yaşadığı evden kurtulmaktır. Çünkü bu ev Serap için "mutlu, huzurlu yuvayı" temsil etmemektedir. Klasik anlatı yapısının kullanıldığı filmlerdeki sıcak yuvayı, mutluluğun olduğu aydınlık yeri temsil eden ev yerine, buradaki ev Serap için tekinsiz, ürkütücü, eniştesi tarafından sürekli rahatsız edildiği bir yere dönüşmüştür. Klasik anlatı sinemasının aksine, çağdaş anlatı sinemasında ev ortamı içerisinde klostrofobik bir atmosfer kullanılmıştır. Suner'in (2006, s. 173) de Hayalet Ev adlı kitabında altını çizdiği şekliyle "ev, kollayıcı, korunaklı bir sığınak değildir. Tersine, özel alanın mahremiyeti şiddetin en akıl almaz biçimlerini kimsenin ulaşamayacağı, müdahale edemeyeceği bir alana çektiği için, ev insanı en çaresiz bırakan yerdir". Dolayısıyla bu ev Serap'ı çaresiz bırakan bir yerdir ve bu yüzden buradan kurtularak babası ile bir evde yaşamak ister. Bu durumda ev Serap için bir tarafta tekinsizliği, diğer tarafta ise "ait" olmayı ifade etmektedir. Filmin ilerleyen sahnelerinde ise Serap eniştesi ve ablasıyla yaşadığı evi terk ederek atölyede yaşamaya başlar. Artık Serap için ev ve aile kavramları yavaş yavaş yıkıma uğramaya başlamaktadır. Arkadaşı Dilber'le atölyede tartıştığı sırada ustabaşı Sultan bu durumu öğrenir. Filmde dikkat çeken bir diğer kadın karakterde Sultan olur. Sultan da kapitalizmin sömürüsüne uğramakta olan bir kadındır. Bu sömürü içerisinde Serap'ı ne kadar anlamaya çalışsa da ona dikkatli olmasını gerektiğini söyler. Çünkü o da başkaları için çalışmaktadır ve bu olay sonucunda işi tehlikeye girebilir. Kadınların işgücü piyasasına katılımları daha çok hizmet sektöründe artış göstermektedir. Fakat Sancar'ın (2016, s.55) da ifade ettiği şekliyle "endüstriyel toplumlara özgü cinsiyet rejimi içinde şekillenen kadın emeğinin hizmet sektöründe ağırlıklı hale dönüşmesinin bir değişim değil, mevcut erkek egemenliğinin yeniden üretimi olduğunu söyleyebiliriz". Dolayısıyla Sultan'da hem kapitalist sistem hem de ataerkil sistem tarafından boyun eğmek zorunda bırakılmış bir kadındır. Sultan film boyunca dominant ve kuralların dışına asla çıkılmasına izin vermeyen bir görünüm çizer. "Burası iş yeri yarın bir gün sorarlarsa ben ne hesap vereceğim" demesi ise kapitalist sistemin hiyerarşik yapısını görünür kılmaktadır. Serap atölye içerisinde ki hiyerarşinin en alt basamağında yer alırken sadece Sultan'a hesap vermekte fakat Sultan'da bir üst basamakta yer alanlara hesap vermek durumundadır. Sultan bu duruma sessiz kalsa da 


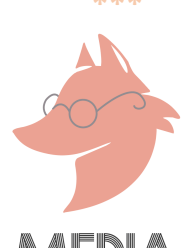

zor bir durumun içerisine girmek istemez ve görürlerse "ben bilmiyorum" diyerek Serap’ı uyarır. Çünkü bu ikili yapı içerisinde, o da işindeki konumunu korumak zorundadır.

Bu filmde Serap'ın tam zıttı bir karakteri oluşturan Dilber ise cinselliği ile ön planda olan bir kadındır. Serap'ın aksine kendisine bakım yapan ve arkadaşları ile eğlenmeyi seven bir kadını yansıtmaktadır. Yusuf'a karşı ilgi duyan ve ona karşı hisler besleyen Serap, Yusuf ve Dilber'i atölyenin bir odasında samimi bir şekilde gördüğü anda çevresindeki cinsel ayrımcılığın ve arzu nesnesi olma halini fark eder. Serap bu durumu Sultan'a anlatır ve Dilber'in işten kovulmasına neden olur. Burada dikkat edilmesi gereken nokta kapitalist üretim süreci içerisinde kadının konumlandırıldığı noktadır. Kadın kolayca gözden çıkarılabilir ve işten kovulabilir fakat erkek ise işe devam eder. Bu durum ise iş dünyası içerisinde cinsiyet temelli bir ayrımcılığın var olduğunu açık bir şekilde göstermektedir. "Bu ayrımcılığın önemli bir kısmı da doğrudan kadın bedeni ve cinselliğine açık ya da dolaylı göndermelerle inşa ediliyor" (Sancar, 2016, s. 84) olmasıdır. Kadınlar iş dünyası içeresinde emek piyasasına dâhil edilirken ve herhangi bir durumun sonucunda işten çıkartıııken ataerkil yapının ürettiği tanımlamaların, önyargıların ve cinsiyetçi söylemlerin etkisinde kalır. Dilber ve Yusuf arasında geçen olayda bu durumu açıklar niteliktedir. Cinsiyetlerinden dolayı her ikisine de farklı davranılmış ve kadın cinsiyet temelli bir ayrımcılığa maruz bırakılmıştır. Yusuf arabasına binip uzaklaşırken, Dilber ise herkesin içiresinde Sultan tarafından "Defol Git!" denilerek kovulmuştur.

Dilber işten kovulduktan sonra ise Serap'ın iş içerisindeki konumu yükselir ve artık ortacı olarak tüm işleri yapmak yerine Dilber'in konumuna geçerek ütü işlerini yapmaya başlar. Burada dikkat edilmesi gereken iki önemli nokta vardır. İlki, bu iki kadın arasındaki ilişkide kapitalizm, onları bir rekabete sürüklemiştir. İkincisi ise bu hiyerarşi içerisinde Serap'ın yerine gelen kişi ise Funda karakteri olur. Atölyede çalışmak üzere Serap'ın sahip olduğu ortacı pozisyona Funda'nın gelmesi ile birlikte de Serap'ın yetiştirme yurdunda büyüdüğüne, oradan kaçtığına ve hayatı ile ilgili birkaç bilgiye daha sahip oluruz. Illerleyen sahnede ise, Serap babasıyla yemek yediği sırada ona sorular sorar. Daha sonra ise babasının kaçamak cevaplar vermesinden sıkılan Serap'ın "Şimdi mi merak ettin? Dışarıda kaldım! Sokakta kaldım!" demesi üzerine babası tarafından tokat yiyerek şiddete maruz kalır. Dolayısıyla Serap eniştesine para vermediğinde, babasına başkaldırdığında ataerkil sistem tarafından ötekileştirilmekte ve şiddetle baş başa bırakılmaktadır. Abisel (2005, s.319) kadının maruz kaldığı şiddetin nedenlerini, erkeğin istediği gibi davranmaması, söylediklerine itiraz etmesi ve söz dinmemesi olarak açıklar. $\mathrm{Bu}$ bakımdan değerlendirildiğinde filmde sorgulayan ve istemediği bir durum karşında direniş gösteren Serap, hayatındaki erkekler tarafından fiziki güç kullanılarak 


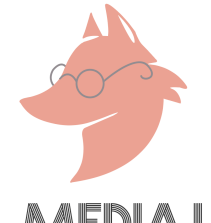

susturulmaya çalışılmaktadır. Ataerkil sistem, toplum içerisinde kadının rollerinin dışına çıkmasına izin vermemek için de erkeğin iktidarını simgeleyen şiddeti kullanır. Serap'ın, babasının fiziksel olarak uyguladığı şiddete sessiz kalması da "erkeğin her ne nedenle olursa olsun öfkelendiğinde bunu denetleyemediği ve karşısındakine şiddet kullanmak zorunda kaldığı" savını destekler niteliktedir (Abisel, 2005, s.320-21). Böylece ataerkil sistem erkeğin, kadın üzerindeki iktidarını bir kez daha meşrulaştırmaktadır.

Filmin sonlarına doğru Serap ve Yusuf'un karşılaşıp bir şeyler içmeye gittikleri sahnede ise Serap, Yusuf'un parasını çalarak bu duruma hırsızlık süsü verir. Daha sonra babasının onu kandırdığını aslında borcunun olmadığını ve kendisiyle yaşamak istemediğini öğrendiği anda da her şeyin farkına varır. Babasının kaçakçılık yapmaya devam ettiğini öğrendiği zamanda babasını durdurmak için polise ihbar eder. Tüm bu durumlarda çağdaş anlatı sinemasında iyi kadın ve kötü kadın olarak bir stereotipleşmenin olmadığı şeklinde okunabilir. Film boyunca Serap, hayat içerisindeki varlığına yakın bir kadın temsili içerisinde yer alır. Serap'ın iyi mi kötü mü olduğunun anlaşılmadığı ikilemler arasında gidip geldiğimiz süreç içerisinde aslında daha da gerçeğe yaklaşırız. Serap'ı onaylamak ile onaylamamak arasında bir ikileme gireriz. Akyürek $(2008$, s.171) bu durumu "geleneksel anlatıdaki, ön gözlem ve bu gözlem sonuçlarından genelleme ve soyutlama yapılarak belirlenen tip yerine, çağdaş anlatılı filmlerde, koşullara göre oluşan insan kavramı öne çıkar. Bu insan kendi içinde çelişkilidir" şeklinde açıklar. Dolayısıyla klasik anlatı sinemasında karakter ile özdeşleşmemiz ve birini seçmemiz beklenir ki bu her zaman iyi taraf olmadır. Çağdaş anlatı sineması ise sorgulamamızı ister ve klasik anlatıda olduğu gibi karakterle özdeşleşmeyi sağlamak yerine özdeşleşmenin kontrol altında tutulmasını amaçlar. "Çağdaş (modern) anlatı formunun asal özelliği, özdeşleşmeyi (mimesis'i) kırıp kendi gerçekliğini bilinçli olarak yorum veya oyun olarak açığa vurması, yani estetik özbilinçliliğe ya da özdüşünümselliğe yol açan bir yapılanmayı içermesidir" (Gürkan ve Oğuz, 2014, s.160). Çağdaş anlatı sinemasının getirdiği bu farklılıklar sonucunda film içerisinde, kadınlığa dair gerçekleri görmeye ve ataerkil sistemi sorgulayarak toplumsal düzen içerisindeki kadının konumunu tekrar düşünmeye başlarız.

Aslında filmin tamamı boyunca, kapitalizm ve ataerkillik tarafından sömürüye uğramasına rağmen nefes almaktan asla vazgeçmeyen işçi bir kadının mücadelesi görülmektedir. Bu ikili yapı içerisinde Serap'tan hayata Funda gibi başlayıp, Dilber gibi devam etmesi ve en sonunda bu düzeni kabullenerek Sultan gibi olması beklenmektedir. Fakat Serap tüm bunlara rağmen bir başkaldırı içindedir ve iyi/kötü kadın stereotiplerinin dışına çıkarak anti-kahraman özellikleri ile ön plana çıkar. Tam da bu noktada klasik 


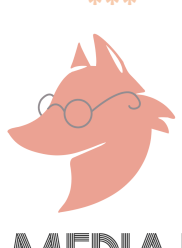

anlatısı sinemasındaki karakter tasarımın aksine modern anlatı sinemasında "kahramanın yüceltimi terk edilmekte ve onlar modern yaşamın parçalanmış kişilikleri olarak anti-kahraman şeklinde çizilmektedirler" (Sözen, 2009, s.88). Filmde diğer karakter isimleri ile değil temsil ettikleri şekilde abla, enişte, baba ve işçi arkadaşlar olarak karşımıza çıkarken, Serap ise bu temsillerin dışında sorgulayan, karşısındaki kişiye hesap soran, kapitalist sistemin içerisinde sıkışıp kalmasına rağmen yenilgiyi kabul etmeyen bir kadın karakter olarak çıkar. Film boyunca da ataerkillik ve kapitalizm arasında nefesi kesilene kadar bir birey olma mücadelesi verir.

\section{SONUÇ}

Kapitalizm ve ataerkillik arasındaki ilişki, cinsiyetler arasındaki eşitsizlikleri de beraberinde getirmiştir. Kadın ve erkek kimliklerinin ayrışmasına neden olan bu cinsiyet eşitsizlikleri avcıtoplayıcı toplumlardan tarım toplumuna doğru geçişte üretim araçlarının değişime uğraması ve bu araçların mülkiyetine erkeğin sahip olmasıyla birlikte daha belirgin bir hale gelmiştir. Özel mülkiyet anlayışının gittikçe güç kazanmasıyla toplumdaki sömürüler artmaya başlamakla kalmamış bunun yanı sıra ataerkil sistemin dayatmalarıyla birlikte kadına karşı sömürü de artmıştır. Kadının konumu ise, dış dünyadan kopartılarak ev-içi üretime dâhil olması şeklinde bir dönüşümü meydana getirmiştir. Ataerkil ideoloji kadın için tanımlanmış olan mekânın ev olduğunu vurgulamış ve kadını üretim sahasından uzaklaştırarak ev içinde yer almasına neden olmuştur. Daha sonra, sanayileşmenin hızlanması ile birlikte ortaya çıkan endüstri devrimi, kadın kimliğini görünür kılmaktan daha da uzaklaştırmış hatta hem ev içi düzenlemelere hem de emek piyasasındaki üretim süreçlerine dâhil ederek çifte bir sömürüye uğramasına neden olmuştur.

Kapitalizm, cinsiyet fark etmeksizin kadın ve erkeği uzun çalışma saatleri ve kötü çalışma koşulları içerisinde az bir ücretle çalışmaya tabi kılmıştır. Dolayısıyla insanlar büyük fabrikalarda mekanik bir sürecin içerisine dâhil olmuşlar ve kapitalizm kendinden önceki dönemlerden daha keskin bir tabakalaşma sürecini getirmiştir. Bu tabakalaşma türlerinden birisi olan toplumsal cinsiyet tabakalaşmaları ise kendinden önceki dönemlere göre belirli farklılıklar göstermiştir. Tam da bu bağlamda kapitalizmin kadına özgürlük getirip getirmediği ya da tanım aksine kadını köleleştiren biçimiyle olumsuz koşulları daha da şiddetli bir biçimde arttırıp arttırmadığı soruları gündeme gelmiştir. Kapitalizm ile birlikte kadın ev-içi durumundan emek piyasasına ücretli iş̧̧i olarak dâhil olmuştur. Fakat ataerkilin zincirlerinden kurtulamamış, ev-içindeki ücretsiz işçi ve kadını çevreleyen anne rolünü devam ettirmek zorunda bırakılmıştır. Bu durumda yeniden üretim sistemleri ile birlikte ataerkil sistem ve kapitalizm arasında kadının ezilmesinin yanı sıra çifte bir sömürüye uğramasına da neden olmuştur. Dolayısıyla kadın, ev içiresinde ataerkil sistemin temsilcisi erkek tarafından, ev içinde yaptığı işler bağlamında sermaye tarafından, en sonda ise ücretim sürecinde işçi olarak kapitalist sistem tarafından sömürüye maruz kalmıştır. 


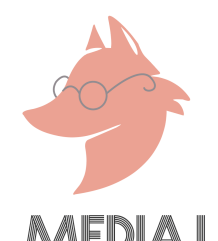

Sinemada bu anlamda kadının uğradığı sömürüyü ele alma biçimi bakımından önemli bir temsil alanı olarak biçimlenirken, özellikle çağdaş anlatı sineması kadının bu sömürüye nasıl uğradığını ve klasik anlatı sinemasındaki iyi-kötü kadın stereotiplerinin dışına çıkarak hayat içerisindeki varlıklarına yakın kadın kimliklerini ele almıştır. Bu bağlamda çağdaş anlatı sineması, kadın kimliğinin yer alış biçiminin incelenmesi bakımından önemli bir örneklem alanı teşkil etmektedir. Kapitalizm ve ataerkillik arasında kadın kimliğinin oluşumunun tartışıldığı Nefesim Kesilene Kadar filmi bu iki yapı arasında direnen ve her zorluğa karşı sisteme boyun eğmeyerek kendini inşa eden güçlü bir kadının hikâyesini ele almaktadır. Film boyunca kadınların evlerde ve özel hayatlarında ataerkil sistemin içerisindeki erkekler tarafından, iş yerlerinde ise kapitalist sistem aracılığıyla işverenleri tarafından bir sömürüye maruz kaldıkları tekrarlanmaktadır. Toplumsal değişim ve dönüşüm süreçleri içerisinde farklılaşan kadın kimliği de sinema için önemli bir inceleme alanıdır. Filmde klasik anlatı sinemasının benimsetmek istediği kadın tiplemesinin aksine anti- kahraman özelliklere sahip bir kadının bu ikili yapı arasındaki özgürleşme mücadelesi gerçekçi bir şekilde temsil edilmiştir. Nefesim Kesilene Kadar filmi, ataerkil sistem ve kapitalizm arasındaki kadın kimliğini emek sömürüsü eşliğinde okuduğu gibi aynı zamanda kadının cinsiyet temelli bir ayrımcılığa da uğradığını ele almıştır. Tüm bunların sonucunda çağdaş anlatı sineması içerisinde kadın kimliğinin toplumsal yapılar tarafından nasıl konumlandığı ve hangi noktalarda görünür olduğu, özgürlük ve kölelik arasında yaşadığı değişimi ortaya koyması bakımından Nefesim Kesilene Kadar filmi konuya gerçekçi bir yön vermiştir. Bu çalışmadaki amaç, sinema temsili üzerinden ataerkil yapı ve kapitalist sistem arasındaki iş birliği sonucunda kadının değişen konumunun, kimliğinin ve mücadelesinin ortaya konması olmuştur.

\section{KAYNAKÇA}

Abisel, N. (2005). Türk Sineması Üzerine Yazılar. Ankara: Phoenix.

Akyürek, F. (2008). Senaryo Yazarı Olmak, Senaryo Yazmak. İstanbul: MediaCat Kitaplar.

Arat, N. (1996). "Türkiye'de Kadınların Çalışma Yaşamında Karşılaştıkları Zorlukların SosyoKültürel Nedenleri”. Türkiye'de Kadın Olmak. Necla Arat (Ed.), (s.43-54). İstanbul: Say.

Aytekin, P. E. (2020). Gender Is Political: Evaluation of Gender in Susuz Yaz (Dry Summer) and Yilanlarin Öcü (Revenge of the Snakes) Films. In Gender and Diversity Representation in Mass Media (pp. 275-294). IGI Global.

Balcı, E.E. (Yönetmen). (2015). Nefesim Kesilene Kadar [Film]. Türkiye

Bora, A. (2005). Kadınların Sınıfı. İstanbul: Illetişim.

Bourdieu, P. (2018). Eril Tahakküm. İstanbul: Bağlam.

Büker, Seçil. (1989). Film ve Gerçek. Eskişehir: Anadolu Üniversitesi Yayınları. 
Connell, R.W. (2017). Toplumsal Cinsiyet ve iktidar: Toplum, Kişi ve Cinsel Politika. İstanbul: Ayrıntı.

Çelik, M., \& Dağ, M. (2017). “Kapitalist iktisadi Düşüncenin Geçirdiği Dönüşümler Üzerine Bir Değerlendirme". Bitlis Eren Üniversitesi iktisadi ve Idari Bilimler Fakültesi Akademik İdüşüm Dergisi, 2(3), 50-70.

Dedeoğlu, S., \& Öztürk, M. Y. (2010). Kapitalizm, Ataerkillik ve Kadın Emeği Türkiye Örneği, İstanbul: Sav.

Ecevit, Y. (1980). "Kentsel Üretim Sürecinde Kadın Emeğinin Konumu ve Değişen Biçimleri". Kadın Bakış Açısından 1980'ler Türkiye'sinde Kadın. Şirin Tekeli (Ed.), (s.105-115). İstanbul: iletişim

Engels, F. (2009). Ailenin, Özel Mülkiyetin ve Devletin Kökeni. Kenan Somer (Çev.). Sol Yayınları, 10.

Fülberth, G. (2011). Kapitalizmin Kısa Tarihi. Sadık Usta (Çev.). İstanbul: Yordam Kitap.

Giddens, A. (2008). Sosyoloji. Cemal Güzel (Çev.). İstanbul: Kırmııı

Gürkan, H. \& Ozan, R. (2014). Butterfly Effect Filmi Örneğinde Karşı Sinemanın Hollywood'da Dönüşümü, Global Media Journal: Turkish Edition, 4(8).

Hayward, S. (2000). Cinema Studies : The Key Concepts. London New York: Routledge.

Hilton, R. (1984). Feodalizmden Kapitalizme Geçiş. Müge Gürer \& Semih Sökmen (Çev.). İstanbul: Metis

Kottak, C. P. (2008). Antropoloji: Insan Çeşitliliğine Bir Bakış. Serpil N. Altuntek (Çev.). Ütopya.

Marshall, G. (2003). Sosyoloji Sözlüğü. Osman Akınhay \& Derya Kömürcü (Çev.). Ankara: Bilim ve Sanat

Marx, K., \& Engels, F. (2014). Alman Ideolojisi. T. Ok \& O. Geridönmez (Çev.). İstanbul: Evrensel Basım

Mies, M. (2012). Ataerki ve Birikim. Yıldız Temurtürkan (Çev.). Dipnot, Ankara.

Mulvey, L.(2019). "Görsel Haz ve Anlatı Sineması". Seçil Büker \& Y. Gürhan Topçu (Ed.), Sinema: Tarih-Kuram-Eleştiri (s.201-218). İstanbul: İthaki.

Nelmes J. Sinemada Cinsiyet ve Cinselliğin Sunumu. Erişim: 24.11.2020, https://kaosgl.org/haber/sinemada-cinsiyet-ve-cinselligin-sunumu 


\section{MEEDIAJ}

Öztürk, S.R. (2000). Sinemada Kadın Olmak: Sanat Filmlerinde Kadın İmgeleri. İstanbul: Alan

Sancar, S. (2016). Erkeklik: Imkânsız iktidar: Ailede, Piyasada ve Sokakta Erkekler. İstanbul: Metis

Scognamillo, G. (2014). Türk Sinema Tarihi. İstanbul: Kabalcı.

Smelik, A. (2008). Feminist Sinema ve Film Teorisi: ve Ayna Çatladı. Deniz Koç (Çev.). İstanbul: Agora.

Sözen, M. (2009). Klasik Anlatı Sinemasında Öykü Kişisi, Yapısal Tasarım Ve Örnek Çözümlemeler. Erciyes Üniversitesi Iletişim Fakültesi Akademik Dergisi, C, 1, 1.

Stalin, J., (1978). Diyalektik ve Tarihsel Materyalizm. (Seçkin Cılızoğlu). Bilim Sosyalizm.

Suner, A. (2006). Hayalet Ev: Yeni Türk Sinemasında Aidiyet, Kimlik ve Bellek. İstanbul: Metis

Şenses, F. (2001). Küreselleşmenin Öteki Yüzü: Yoksulluk. İstanbul: Iletişim.

Toksöz, G. (2012). Kalkınmada Kadın Emeği, İstanbul: Varlık.

Wallerstein, I. (2012). Tarihsel Kapitalizm ve Kapitalist Uygarlık. Necmiye Alpay (Çev.). İstanbul: Metis

Woolf, V. (2018). Kendine Ait Bir Oda. İlknur Özdemir (Çev.). İstanbul: Kırmızı Kedi

Yıldırım, S. (2018) "Feminist Çalışmalarda Kadın Deneyimlerinin Önemi: Simone de Beauvoir Örneği". Anemon Muş Alparslan Üniversitesi Sosyal Bilimler Dergisi, 7(1), 145-150.

Zetkin, K., Krupskaya, N., Pieck, W. \& Yarkın, I. (1996). Kadın Sorunu Üzerine Seçme Yazılar \& Clara Zetkin Üzerine. İstanbul: İnter. 